\title{
Evaluation of Nutrient Concentration and Uptake in Magnesium and Iron Deficient Gerbera
}

\author{
Shiva Kumar Udayana ${ }^{1 *}$, N.B. More $^{2}$ and Anandkumar Naorem ${ }^{1}$ \\ ${ }^{1}$ Department of Agricultural Chemistry and Soil science, Bidhan Chandra Krishi \\ Viswavidyalaya, Mohanpur, Nadia, West Bengal-741252, India \\ ${ }^{2}$ Department of Soil Science and Agricultural Chemistry, College of Agriculture, Pune, Mahatma \\ Phule Krishi Vidyapeeth, Maharashtra- 411005, India \\ *Corresponding author
}

\section{A B S T R A C T}

A pot culture experiment was conducted using Goliath cultivar of Gerbera as a test crop to study the importance of Iron $(\mathrm{Fe})$ and Magnesium $(\mathrm{Mg})$ in the cultivation

Keywords

Gerbera, Iron, Magnesium,

Nutrient

concentration, Nutrient uptake.

Article Info

Accepted:

19 May 2017

Available Online:

10 June 2017 of Gerbera. The experiment was laid out with different treatments (factor A) including T1 as control (complete nutrition), T2 (excluding Magnesium) and T3 (excluding Iron), thereby accounting for 16 treatment combinations with five different days of harvesting (factor B). In both the deficiency cases (T2 and T3), there is a significant reduction in nutrient concentration of $\mathrm{Mg}$ and $\mathrm{Fe}$ in different plant parts such as crown + leaves $(0.26 \%$ and $167 \mathrm{ppm})$, roots $(0.15 \%$ and 145 $\mathrm{ppm})$ and flowers $(0.08 \%$ and $60 \mathrm{ppm})$ respectively. The nutrient uptake by gerbera plant also reduced due to the nutrient deficient treatments because of the lower production of the dry matter and also the lower nutrient concentration which causes a great setback in the cultivation of the gerbera due to low quality flowers with lower vase life and less aesthetic value. The experiment will generate information on the importance of Magnesium and Iron in the nutrition of gerbera which has got higher floricultural importance at international trade.

\section{Introduction}

Gerbera (Gerbera jamesonii; family Asteraceae) is one of the most popular commercial flower crop and ranks $4^{\text {th }}$ among cut flower demands (Sujatha et al., 2002). In India, 0.190 million hectares of area is under flower cultivation with a production of 1.031 million loose of flowers and 690.27 million of cut flowers in the year 2010-2011. Maharashtra is one of the pioneer states known for its protected flower cultivation and the area under protected gerbera cultivation is mostly confined in Pune, Satara, Kolhapur, Nashik etc. that has nearly 600 hectares of land out of which more than 100 hectares area is being adopted for gerbera cultivation with 1476 lakh flowers per year with a productivity of 250 flowers $/ \mathrm{m}^{2}$ (Anonymous, 2010). The success of gerbera cultivation under polyhouse depends largely on nutrient management apart from other factors. Plant nutrition is a difficult subject to understand completely, partially because of the variation 
between different plants and even between different species or individuals of a given clone. An element present at a low level may cause deficiency symptoms, while the same element at a higher level may cause toxicity. Further, deficiency of one element may present as symptoms of toxicity for another element.

Deficiency of some nutrients may delay flowering and also reduces the aesthetic value. Balancing the plants growth, need periodic monitoring to assure the nutritional requirements are being met. When growers face nutritional problems with visual symptoms, knowing key symptoms of nutrient disorders with critical tissue concentrations would assist growers in problem identification. So, in this research paper, we aimed to study the effect of $\mathrm{Mg}$ and $\mathrm{Fe}$ on nutrient concentration and uptake of gerbera.

\section{Materials and Methods}

The present study was conducted out at the Hi-Tech Floriculture and Vegetable Production Project, College of Agriculture, Pune-5 during August 2013 to February 2014.

The details of the materials used and techniques adopted for this investigation are presented as follows.

\section{Planting material}

Goliath cultivar of gerbera was selected for present study. The tissue cultured plantlets of Goliath cultivar were procured from M/S Kumar Florist Pvt. Ltd., Pune- 36.

\section{Media}

Cocopeat was obtained from Sterlin Farm Research and Services Pvt. Ltd. Cochin (Kerala).

\section{Earthen pots}

Earthen pots $(30 \mathrm{~cm}$ height, $15 \mathrm{~cm}$ upper diameter and 5 litres capacity) were used for experiment. Each pot was filled manually with $0.625 \mathrm{~kg}$ cocopeat.

\section{Saline bottles}

Saline bottles having $500 \mathrm{ml}$ capacity were used for this experiment. These bottles were used after cleaning firstly with dilute nitric acid and then washed with water for $2-3$ times. Total forty five bottles were used for forty five plants as per the treatments.

\section{Fertilizers}

The commercial grade water soluble inorganic fertilizers were used for experimental purpose. Their elemental composition is as below in table 1 .

\section{Polyhouse management}

The polyhouse was naturally ventilated $(\mathrm{GH}-$ 1) type and UV stabilized 200 micron thickness polythene film was used as cladding material. For maintaining temperature, 50 per cent, shade net was provided in the polyhouse. The manually operated movable curtains were fixed on side walls to cover ventilators. The misting system was provided for control of temperature and humidity.

\section{Factor A}

All nutrients as control (T1)

All nutrients excluding magnesium (T2)

All nutrients excluding iron (T3)

\section{Factor B}

115 days of harvesting (D1)

130 days of harvesting (D2)

145 days of harvesting (D3)

160 days of harvesting (D4)

175 days of harvesting (D5) 


\section{Treatment details}

All plants were supplied with recommended dose of fertilizers up to 100 days after transplantation through drip irrigation.

\section{Before flowering}

200-60-250 mg N, $\quad \mathrm{P}_{2} \mathrm{O}_{5} \quad$ and $\mathrm{K}_{2} \mathrm{O} /$ plant/alternate day.

\section{After flowering}

350-60-300 $\mathrm{mg} \quad \mathrm{N}, \quad \mathrm{P}_{2} \mathrm{O}_{5} \quad$ and $\mathrm{K}_{2} \mathrm{O}$ /plant/alternate day.

\section{All nutrients}

Include complete dose of fertilizers.

\section{Treatment combinations}

Factor A (3) x Factor B (5) $=15\left(\mathrm{~T}_{1}\right.$ to $\left.\mathrm{T}_{15}\right)$

$\mathrm{T}_{16}$ :plant harvested at $100 \mathrm{DAP}$ which was supplied all nutrients after recording all observations.

\section{Preparation of nutrient solutions}

\section{All nutrients treatment}

Different nutrient solutions were prepared separately in tank A and B as per the treatments as shown in table 2 .

\section{Treatment excluding magnesium}

In Tank B, the quantity of magnesium sulphate $(600 \mathrm{~g})$ for preparation of 25 litres nutrient solution was not included in the treatment excluding Mg. The quantity of sulphur in the form of sulphate $(216 \mathrm{~g})$ supplied through magnesium sulphate was balanced with $80 \mathrm{~g}$ bentosulf which contains 90 per cent elemental sulphur for fulfilling the requirement of sulphur to gerbera. The remaining nutrients were supplied as per the treatment with all nutrients in Tank A and Tank B.

\section{Treatment excluding iron}

In Tank A, Fe EDDHA was excluded and remaining nutrients are given as per the all nutrient treatment.

\section{Experimental Methodology}

The experiment was started by transplanting the plantlets of Goliath cultivar of gerbera at 3 - 4 leaf stage for 16 treatment combinations in factorial completely randomized design with three replications in 48 pots. Total 48 earthen pots were used for experiment. Each pot was filled with $0.625 \mathrm{~kg}$ cocopeat. The cocopeat bricks before utilization were loosened by immersing in plain tap water. Then calcium nitrate treatment was given to leach out the salts like sodium. Generally, 8$10 \mathrm{~kg}$ calcium nitrate is sufficient for $100 \mathrm{~kg}$ bricks. The cocopeat was washed thoroughly on the polyfilm surface in the tractor trolley, so that leaching of salts is done easily. After transplanting, the plantlets were drenched with a mixture of $100 \mathrm{ml}$ of Bavistin $\left(1.5 \mathrm{~g} \mathrm{~L}^{-}\right.$ $\left.{ }^{1}\right)$ and Keradex $\left(1 \mathrm{ml} \mathrm{L}^{-1}\right)$.

One week after transplanting, these plantlets were drenched with $80 \mathrm{ml}$ of Tripla (19: 19: 19)@ $1 \mathrm{~g} \mathrm{~L}^{-1}$ for better root development. Watering was given manually to all plants up to 21 days of transplanting. Fertigation through drippers was started after 21 DAP and continued up to 100 DAP. There after the treatments were started and fertigation was given through saline bottles @ 500ml per plant per alternate day as per the treatments. For fertigation, $10 \mathrm{ml}$ stock solution from tank A and tank B were used which were diluted in one liter of irrigation water and 1.0 $\mathrm{ml}$ of concentrated nitric acid was added for maintaining the $\mathrm{pH}$ of the solution. These fertigations through saline bottles were continued up to 175 DAP i.e., till the final harvest on every alternate day. 


\section{Plant analysis}

Plant analysis was carried out after digesting the oven dried plant sample by di-acid digestion using $\mathrm{H}_{2} \mathrm{SO}_{4}$ and $\mathrm{H}_{2} \mathrm{O}_{2}$ for analyzing the nutrient concentration and uptake. Nutrient uptake was calculated from dry matter (crown + leaves and flowers) and nutrient concentration.

Nutrient uptake $=($ Nutrient content $\mathrm{X}$ dry matter content) / 100

\section{Results and Discussion}

Effect of nutrients on periodical nutrient concentration

Effect of nutrients on $\mathrm{Mg}$ content in crown + leaves of gerbera at different days after planting

Significantly lower $\mathrm{Mg}$ content in crown + leaves $(0.26 \%$ as a mean value) was observed in treatment omitting $\mathrm{Mg}$ as compared to all nutrients treatment (Figure 1). There was significant difference in $\mathrm{Mg}$ content with days and significantly higher $\mathrm{Mg}$ content $(0.41 \%)$ was observed at 115 DAP (D1). As the number of days increased, the $\mathrm{Mg}$ content decreased in crown + leaves.

The lower $\mathrm{Mg}$ content in crown + leaves found in treatment omitting $\mathrm{Mg}$ as $\mathrm{Mg}$ was not supplied to these plants. The above findings are similar to the findings of Anjaneyulu (2008) who found that the $\mathrm{Mg}$ content in leaves less than $0.36 \%$ was considered deficient according to the leaf nutrient norms using DRIS technique in gerbera. The Mg content in crown + leaves of all nutrients and iron excluding treatments were similar to those reported by Kossowski and Strojny (1983) and Gurav and Kale (2002) which shows the importance of $\mathrm{Mg}$ in gerbera nutrition.
Effect of nutrients on $\mathrm{Mg}$ content in roots of gerbera at different days after planting

From figure 2, it can be seen that significantly lower $\mathrm{Mg}$ content in roots $(0.15 \%$ as mean value) was observed in treatment excluding $\mathrm{Mg}$. As the number of days increases, the $\mathrm{Mg}$ content decreased in roots. The lower $\mathrm{Mg}$ content in roots of treatment excluding $\mathrm{Mg}$ was due to the deduction of $\mathrm{Mg}$ supply to these plants and also due to the inhibition of sugar transport out of magnesium deficient leaves resulting in the inhibition of the root growth which are in conformity with Cakmak et al., 1994; Fischer et al., 1998; Hermans et al., 2004, 2005; Hermans and Verbruggen, 2005.

Effect of nutrients on $\mathrm{Mg}$ content in flowers of gerbera at different days after planting

The $\mathrm{Mg}$ content was significantly lower in treatment without $\mathrm{Mg}(0.08 \%)$. As the number of days increases, there was an increase in the $\mathrm{Mg}$ content in flower with all nutrients and treatment excluding iron but decreased with treatment excluding $\mathrm{Mg}$ (Figure 3). There was no significant difference in $\mathrm{Mg}$ content with days. The lower $\mathrm{Mg}$ content of flowers in treatment excluding $\mathrm{Mg}$ was due to the inhibition of sugar transport out of magnesium deficient leaves resulting in lower quality flowers and also reduction in the vase life of flowers as reported by Cakmak and Yazici (2010) and Hermans et al., 2004, 2005.

Effect of nutrients on $\mathrm{Fe}$ content in crown + leaves and roots of gerbera at different days after planting

Significantly lower $\mathrm{Fe}$ content in crown + leaves and roots was observed in treatment excluding iron (Figures 4 and 5). With increase in number of days, iron content decreased in crown + leaves and roots. 
Table.1 Sources and chemical composition of nutrient solution

\begin{tabular}{|l|l|l|l|l|}
\hline $\begin{array}{l}\text { Sl. } \\
\text { No. }\end{array}$ & Name of the source & $\begin{array}{l}\text { Molecular } \\
\text { Weight }\end{array}$ & $\begin{array}{l}\text { Chemical } \\
\text { Formula }\end{array}$ & Nutrient Content (\%) \\
\hline 1 & Calcium nitrate & 236 & $\mathrm{Ca}\left(\mathrm{NO}_{3}\right)_{2} \cdot 4 \mathrm{H}_{2} \mathrm{O}$ & $\mathrm{N}=15.50, \mathrm{Ca}=18.80$ \\
\hline 2 & Fe EDDHA 6\% & - & $\mathrm{Fe}-\mathrm{EDDHA}$ & $\mathrm{Fe}=6.00$ \\
\hline 3 & Nitric acid & 63 & $\mathrm{HNO}_{3}$ & $\mathrm{~N}=31.55 \mathrm{w} / \mathrm{v}(22.22 \mathrm{v} / \mathrm{v})$ \\
\hline 4 & Mono potassium phosphate & 136 & $\mathrm{KH}_{2} \mathrm{PO}_{4}$ & $\mathrm{P}_{2} \mathrm{O}_{5}=52, \mathrm{~K}_{2} \mathrm{O}=34$ \\
\hline 5 & Potassium sulphate & 174 & $\mathrm{~K}_{2} \mathrm{SO}_{4}$ & $\mathrm{~K}_{2} \mathrm{O}=50, \mathrm{SO}_{4}=52.5$ \\
\hline 6 & Potassium nitrate & 101 & $\mathrm{KNO}_{3}$ & $\mathrm{~N}=13, \mathrm{~K}_{2} \mathrm{O}=45$ \\
\hline 7 & Magnesium sulphate & 246 & $\mathrm{MgSO}_{4} \cdot 7 \mathrm{H}_{2} \mathrm{O}$ & $\mathrm{Mg}=9.60, \mathrm{SO}_{4}=36$ \\
\hline 8 & Bentosulf & - & - & $\mathrm{Elemental} \mathrm{S}=90 \%$ \\
\hline 9 & Borax & 381.2 & $\mathrm{Na}_{2} \mathrm{~B}_{4} \mathrm{O}_{7} \cdot 10 \mathrm{H}_{2} \mathrm{O}$ & $\mathrm{B}=11.33$ \\
\hline 10 & Manganese sulphate & 169 & $\mathrm{MnSO}_{4} \cdot \mathrm{H}_{2} \mathrm{O}$ & $\mathrm{Mn}=30.50, \mathrm{SO}_{4}=51$ \\
\hline 11 & Zinc sulphate & 179 & $\mathrm{ZnSO}_{4} \cdot \mathrm{H}_{2} \mathrm{O}$ & $\mathrm{Zn}=33, \mathrm{SO}_{4}=15$ \\
\hline 12 & Copper sulphate & 249.5 & $\mathrm{CuSO}_{4} \cdot 5 \mathrm{H}_{2} \mathrm{O}$ & $\mathrm{Cu}=25.45, \mathrm{SO}_{4}=38.47$ \\
\hline 13 & Sodium molybdate & 241.96 & $\mathrm{Na}_{2} \mathrm{MoO}_{4} \cdot 2 \mathrm{H}_{2} \mathrm{O}$ & $\mathrm{Na}=19.01, \mathrm{Mo}_{2}=39.65$ \\
\hline
\end{tabular}

Table.2 Preparation of stock solution A) All nutrients treatment

\begin{tabular}{|c|c|c|c|c|c|}
\hline $\begin{array}{l}\text { Sl. } \\
\text { No. }\end{array}$ & $\begin{array}{l}\text { Name of salt/ } \\
\text { fertilizer }\end{array}$ & $\begin{array}{l}\text { Quantity required } \\
\text { for preparation of } \\
1000 \text { liters of } \\
\text { stock solution }\end{array}$ & $\begin{array}{l}\text { Quantity } \\
\text { required for } \\
\text { preparation of } 25 \\
\text { liters of stock } \\
\text { solution }\end{array}$ & $\begin{array}{l}\text { Nutrient supplied } \\
\text { through } \\
1000 \text { liters }\end{array}$ & $\begin{array}{l}\text { Nutrient } \\
\text { supplied } \\
\text { through } \\
25 \text { liters }\end{array}$ \\
\hline \multicolumn{6}{|c|}{ Tank A } \\
\hline 1 & Calcium nitrate & $65 \mathrm{~kg}$ & $1.625 \mathrm{~kg}$ & $\begin{array}{l}10.075 \mathrm{~kg} \mathrm{~N}, 12.22 \\
\mathrm{~kg} \mathrm{Ca}\end{array}$ & $\begin{array}{l}251.85 \mathrm{~g} \mathrm{~N}, \\
305.5 \mathrm{~g} \mathrm{Ca}\end{array}$ \\
\hline 2 & Fe EDDHA 6\% & $3 \mathrm{~kg}$ & $75 \mathrm{~g}$ & $0.18 \mathrm{~kg} \mathrm{Fe}$ & $4.5 \mathrm{~g} \mathrm{Fe}$ \\
\hline 3 & Nitric acid & $500 \mathrm{ml}$ & $12.5 \mathrm{ml}$ & $157.76 \mathrm{~g} \mathrm{~N}$ & $3.94 \mathrm{~g} \mathrm{~N}$ \\
\hline \multicolumn{6}{|c|}{ Tank B } \\
\hline 1 & $\begin{array}{l}\text { Mono potassium } \\
\text { phosphate }\end{array}$ & $20 \mathrm{~kg}$ & $500 \mathrm{~g}$ & $\begin{array}{l}10.4 \mathrm{~kg} \mathrm{P}_{2} \mathrm{O}_{5}, 6.8 \mathrm{~kg} \\
\mathrm{~K}_{2} \mathrm{O}\end{array}$ & $\begin{array}{l}260 \mathrm{~g} \mathrm{P}_{2} \mathrm{O}_{5}, 170 \\
\mathrm{~g} \mathrm{~K}_{2} \mathrm{O}\end{array}$ \\
\hline 2 & $\begin{array}{l}\text { Potassium } \\
\text { sulphate }\end{array}$ & $20 \mathrm{~kg}$ & $500 \mathrm{~g}$ & $\begin{array}{l}10 \mathrm{~kg} \mathrm{~K} 2 \mathrm{O}, 10.5 \mathrm{~kg} \\
\mathrm{SO}_{4}\end{array}$ & $\begin{array}{l}250 \mathrm{~g} \mathrm{~K}_{2} \mathrm{O} \\
262.5 \mathrm{~g} \mathrm{SO}_{4}\end{array}$ \\
\hline 3 & $\begin{array}{l}\text { Potassium } \\
\text { nitrate }\end{array}$ & $8 \mathrm{~kg}$ & $200 \mathrm{~g}$ & $\begin{array}{l}1.04 \mathrm{~kg} \mathrm{~N}, 3.6 \mathrm{~kg} \\
\mathrm{~K}_{2} \mathrm{O}\end{array}$ & $\begin{array}{l}26 \mathrm{~g} \mathrm{~N} \\
90 \mathrm{~g} \mathrm{~K}_{2} \mathrm{O}\end{array}$ \\
\hline 4 & $\begin{array}{l}\text { Magnesium } \\
\text { sulphate }\end{array}$ & $24 \mathrm{~kg}$ & $600 \mathrm{~g}$ & $\begin{array}{l}2.304 \mathrm{~kg} \mathrm{Mg}, 8.640 \\
\mathrm{~kg} \mathrm{SO}_{4}\end{array}$ & $\begin{array}{l}57.6 \mathrm{~g} \mathrm{Mg}, 216 \\
\mathrm{~g} \mathrm{SO}_{4}\end{array}$ \\
\hline 5 & Borax & $270 \mathrm{~g}$ & $6.75 \mathrm{~g}$ & $30.591 \mathrm{~g} \mathrm{~B}$ & $0.7647 \mathrm{~g} \mathrm{~B}$ \\
\hline 6 & $\begin{array}{l}\text { Manganese } \\
\text { sulphate }\end{array}$ & $100 \mathrm{~g}$ & $2.5 \mathrm{~g}$ & $\begin{array}{l}32.5 \mathrm{~g} \mathrm{Mn}, 51.00 \mathrm{~g} \\
\mathrm{SO}_{4}\end{array}$ & $\begin{array}{l}0.763 \mathrm{~g} \mathrm{Mn} \\
1.275 \mathrm{~g} \mathrm{SO}_{4}\end{array}$ \\
\hline 7 & Zinc sulphate & $170 \mathrm{~g}$ & $4.25 \mathrm{~g}$ & $\begin{array}{l}56.1 \mathrm{~g} \mathrm{Zn}, 25.5 \mathrm{~g} \\
\mathrm{SO}_{4}\end{array}$ & $\begin{array}{l}1.4025 \mathrm{~g} \mathrm{Zn}, \\
0.638 \mathrm{~g} \mathrm{SO}_{4}\end{array}$ \\
\hline 8 & Copper sulphate & $50 \mathrm{~g}$ & $1.25 \mathrm{~g}$ & $\begin{array}{l}12.725 \mathrm{~g} \mathrm{Cu}, 19.235 \\
\mathrm{~g} \mathrm{SO}_{4}\end{array}$ & $\begin{array}{l}0.3181 \mathrm{~g} \mathrm{Cu} \\
0.481 \mathrm{~g} \mathrm{SO}_{4}\end{array}$ \\
\hline 9 & $\begin{array}{l}\text { Sodium } \\
\text { molybdate }\end{array}$ & $10 \mathrm{~g}$ & $0.25 \mathrm{~g}$ & $\begin{array}{l}1.901 \mathrm{~g} \mathrm{Na}, 3.965 \mathrm{~g} \\
\text { Mo }\end{array}$ & $\begin{array}{l}0.0475 \mathrm{~g} \mathrm{Na}, \\
0.099 \mathrm{~g} \mathrm{Mo}\end{array}$ \\
\hline 10 & Nitric acid & $500 \mathrm{ml}$ & $12.5 \mathrm{ml}$ & $157.76 \mathrm{~g} \mathrm{~N}$ & $3.94 \mathrm{~g} \mathrm{~N}$ \\
\hline
\end{tabular}


Table.3 Effect of nutrients on $\mathrm{Mg}$ uptake by gerbera plant at different Days after planting $\left(\mathrm{g}\right.$ plant $\left.{ }^{-1}\right)$

\begin{tabular}{|c|c|c|c|c|c|c|}
\hline Treatments & D1 & D2 & D3 & D4 & D5 & Mean \\
\hline$T_{1}$ & 0.12 & 0.15 & 0.18 & 0.22 & 0.25 & 0.19 \\
\hline $\mathbf{T}_{2}$ & 0.11 & 0.11 & 0.10 & 0.08 & 0.05 & 0.09 \\
\hline $\mathbf{T}_{3}$ & 0.11 & 0.11 & 0.12 & 0.12 & 0.12 & 0.12 \\
\hline Mean & 0.11 & 0.13 & 0.14 & 0.14 & 0.14 & \\
\hline \multicolumn{4}{|c|}{ Treatment } & DAP & \multicolumn{2}{|c|}{ Interaction } \\
\hline \multicolumn{2}{|c|}{ SE $( \pm)$} & \multicolumn{2}{|c|}{0.002} & 0.003 & \multicolumn{2}{|c|}{0.005} \\
\hline \multicolumn{2}{|c|}{ CD5\% } & \multicolumn{2}{|c|}{0.006} & 0.008 & \multicolumn{2}{|c|}{0.014} \\
\hline
\end{tabular}

Observation at 100 DAP: $0.12 \mathrm{~g}$ plant $^{-1}$

Table.4 Effect of nutrients on Fe uptake by gerbera plant at different

Days after planting (mg plant $\left.{ }^{-1}\right)$

\begin{tabular}{|c|c|c|c|c|c|c|}
\hline Treatments & D1 & D2 & D3 & D4 & D5 & Mean \\
\hline $\mathbf{T}_{\mathbf{1}}$ & 7.90 & 9.74 & 11.27 & 13.00 & 14.57 & $\mathbf{1 1 . 2 9}$ \\
\hline $\mathbf{T}_{\mathbf{2}}$ & 7.52 & 8.78 & 9.49 & 9.76 & 10.34 & $\mathbf{9 . 1 8}$ \\
\hline $\mathbf{T}_{\mathbf{3}}$ & 6.56 & 6.10 & 5.10 & 3.91 & 2.59 & $\mathbf{4 . 8 5}$ \\
\hline Mean & $\mathbf{7 . 3 3}$ & $\mathbf{8 . 2 1}$ & $\mathbf{8 . 6 2}$ & $\mathbf{8 . 8 9}$ & $\mathbf{9 . 1 7}$ & \\
\hline
\end{tabular}

\begin{tabular}{|c|c|c|c|}
\hline & Treatment & DAP & Interaction \\
\hline SE $( \pm)$ & 0.13 & 0.098 & 0.220 \\
\hline CD5\% & 0.363 & 0.281 & 0.628 \\
\hline
\end{tabular}

Observation at 100 DAP: $7.56 \mathrm{mg}$ plant $^{-1}$

Fig.1 Effect of nutrients on Mg content in crown + leaves of gerbera at Different days after planting

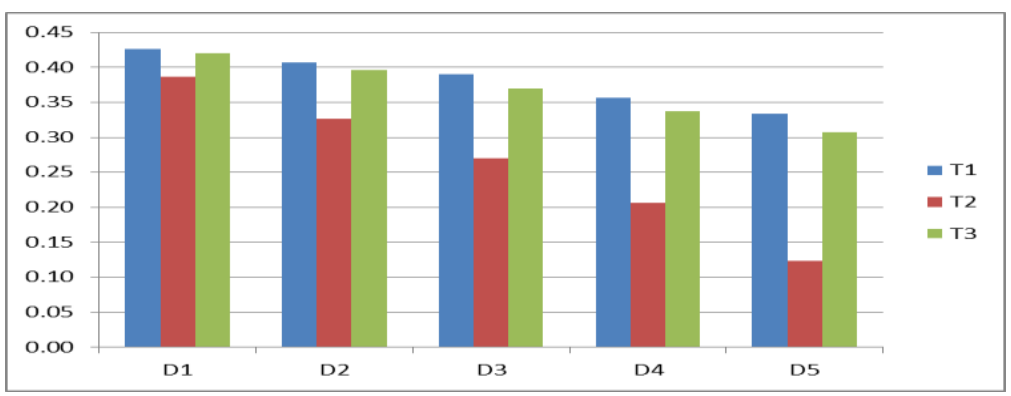

Fig.2 Effect of nutrients on $\mathrm{Mg}$ content in roots of gerbera at different days after planting

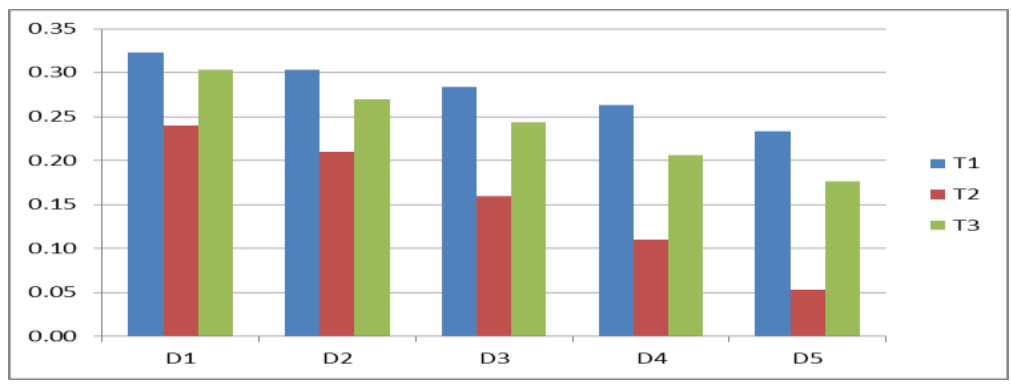


Fig.3 Effect of nutrients on $\mathrm{Mg}$ content in flowers of gerbera at different days after planting

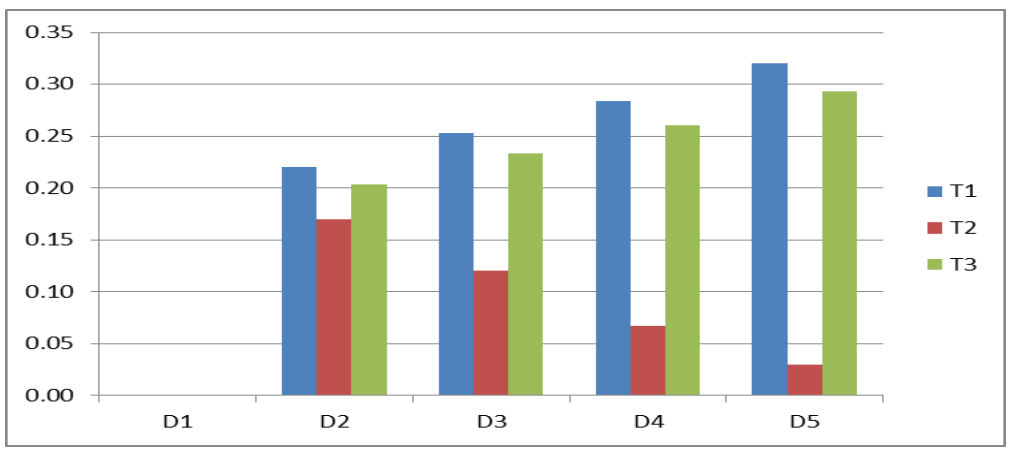

Fig.4 Effect of nutrients on Fe content in crown + leaves of gerbera at Different days after planting

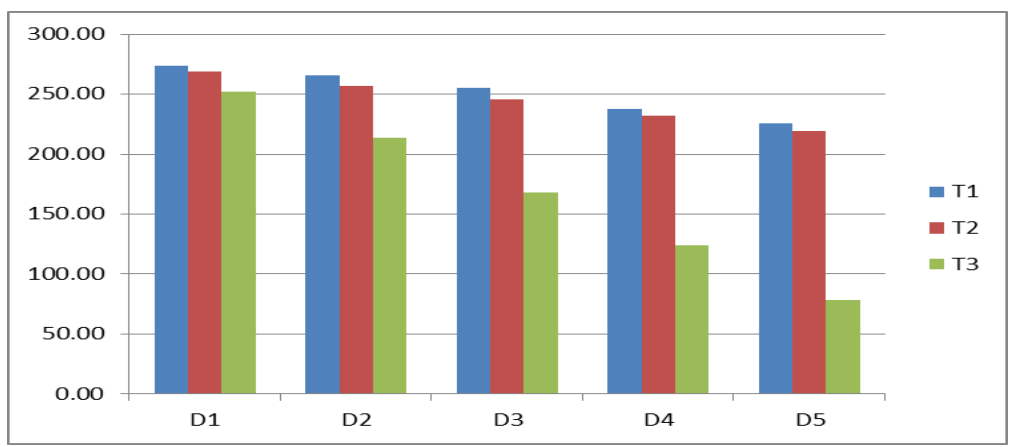

Fig.5 Effect of nutrients on Fe content in roots of gerbera at different days after planting

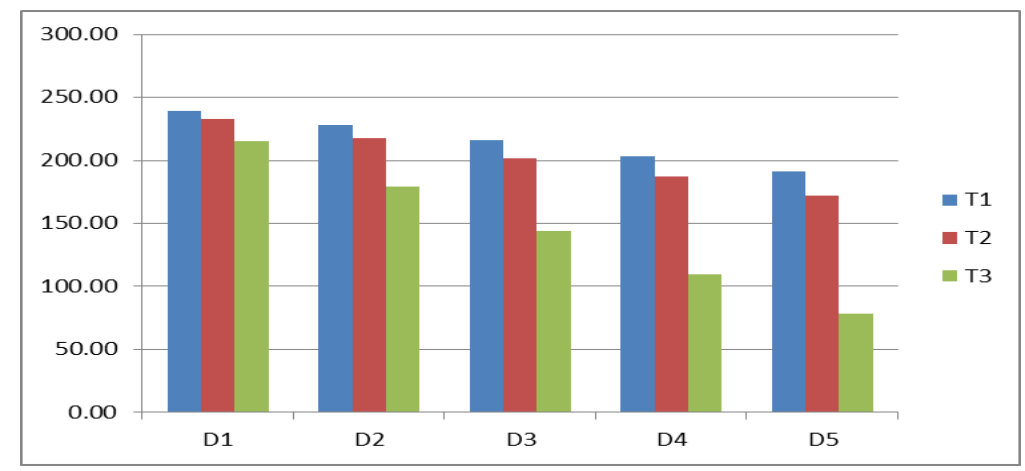

Fig.6 Effect of nutrients on Fe content in flowers of gerbera at different days after planting

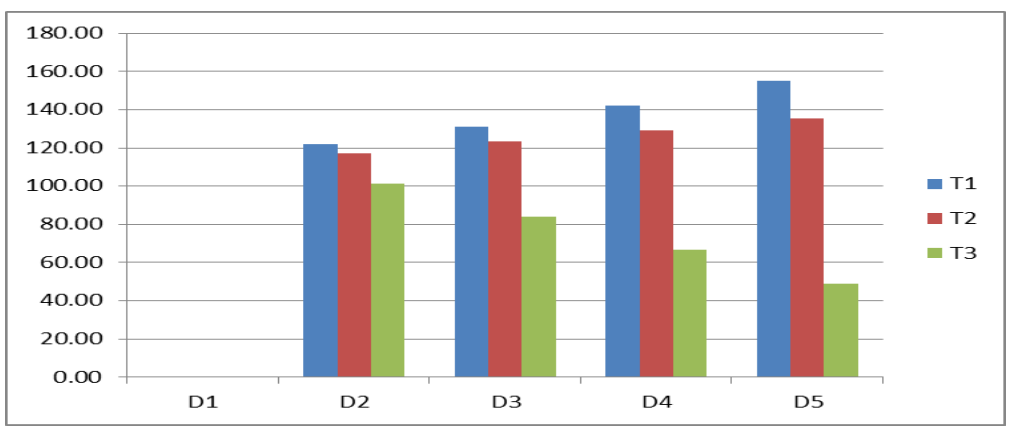


There was a significant difference in $\mathrm{Fe}$ content with days and significantly higher $\mathrm{Fe}$ content was observed at 115 DAP (D1). The Fe content in crown + leaves and roots were found lowest in treatment excluding $\mathrm{Fe}$ as $\mathrm{Fe}$ was not supplied to these plants. The above findings were similar to the findings of Anjaneyulu (2008) who had given the leaf nutrient norms with leaf Fe content $164-224$ ppm and less than 163 ppm were considered as low and deficient in $\mathrm{Fe}$ content.

\section{Effect of nutrients on Fe content in flowers of gerbera at different days after planting}

The Fe content was significantly lower (Figure 6) in treatment excluding iron (60.21 ppm as mean value). As the number of days increased, there was an increase in the $\mathrm{Fe}$ content in flower with all nutrients and treatment excluding $\mathrm{Mg}$ but decreased with treatment excluding iron. There was no significant difference in Fe content with days. The lower Fe content in flowers resulted in the disruption of normal metabolism of the crop due to nutritional disorder of the plant (Da Silva et al., 2016) (Table 3).

\section{Effect of nutrients on periodical nutrient uptake of gerbera}

Effect of nutrients on Mg uptake by gerbera plant at different days after planting

The $\mathrm{Mg}$ uptake by gerbera plant was significantly lower in treatment excluding $\mathrm{Mg}$ (0.09 $\left.\mathrm{g} \mathrm{plant}^{-1}\right)$ as compared to all nutrients treatment. The $\mathrm{Mg}$ uptake by gerbera plant was also lower in treatment excluding iron $\left(0.12 \mathrm{~g} \mathrm{plant}^{-1}\right)$ as compared to all nutrients treatment which might be due to the interaction effect with other nutrients. The $\mathrm{Mg}$ uptake by gerbera plant was lower in case of treatment without $\mathrm{Mg}$ might be due to lower dry matter because of interveinal chlorosis and lower $\mathrm{Mg}$ concentration in the different plant parts as $\mathrm{Mg}$ plays an essential role in chlorophyll formation in all photosynthetic organisms (Beale, 1999).

\section{Effect of nutrients on Fe uptake by gerbera plant at different days after planting}

From table 4, it can be seen that the Fe uptake by the plant was significantly lower in treatment excluding iron $\left(4.85 \mathrm{mg} \mathrm{plant}^{-1}\right)$ as compared to all nutrients treatment. The Fe uptake by the plant was also lower in treatment excluding $\mathrm{Mg}$ (9.18 mg plant ${ }^{-1}$ ) as compared to all nutrients treatment. The Fe uptake by the plant increased with increase in days with significantly higher uptake at 175 DAP (9.17 mg plant ${ }^{-1}$ ). The Fe uptake by gerbera plant was lower in case of treatment excluding $\mathrm{Fe}$ might be due to lower dry matter because of interveinal chlorosis as $\mathrm{Fe}$ is a precursor in the biosynthesis of tetrapyrroles including chlorophylls and heme, whose deficiency reduces the growth of both shoot and root of plants (Kumar and Soll, 2000).

The experiment revealed the importance of Magnesium and Iron in maintaining the flower quality of Gerbera. These essential nutrients have crucial roles in the plant growth and development, their deficiency indicating significant reduction of quality (test parameters) in Gerbera. Further research can be opted for nutrient interaction in flower crops which can generate information on the effect of nutrient mixtures in maintaining the quality of flower crops. Critical limits of these nutrients must be identified especially for floriculture crops as the range of optimum levels of these nutrients are narrow.

\section{References}

Anjaneyulu, K. 2008. Diagnostic leaf nutrient norms and identification of yield 
limiting nutrients in gerbera grown under protected conditions using DRIS. Indian J. Horticulture, 65: 176-179.

Anonymous. 2010. Marathi booklet on gerbera cultivation under polyhouse. MPKV/ EXTN.PUB.No. 701/ 2010.

Beale, S.I. 1999. Enzymes of chlorophyll biosynthesis. Photosynthesis Res., 60: 43-73.

Cakmak, I. and Yazici, A.M. 2010. Magnesium: A forgotten element in crop production. Better Crops, 94(2): 23-25.

Cakmak, I., Hengeler, C. and Marschner, H. 1994. Partitioning of shoot and root dry matter and carbohydrates in bean plants suffering from phosphorus, potassium and magnesium deficiency. J. Exp. Bot., 45: $1245-1250$.

Da Silva, G.P., Prado, R.M., Moda, L.R. and Silva, S.L.O. 2016. Growth, nutrient accumulation and nutritional efficiency of sunn hemp in function of nutrient omission. Afr. J. Agri. Res., 11(6): 494499.

Fischer, E.S., Lohaus, G., Heineke, D. and Heldt, H.W. 1998. Magnesium deficiency resulted in accumulation of carbohydrates and amino acids in source and sink leaves of spinach. Physiologia Plantarum, 102: 16-20.

Gurav, S.B. and Kale, R.H. 2002.Cultivation of gerbera. Proc. Nat. Training course on Hi-tech floriculture, 16-2, Dec. Mahatma Phule Krishi Vidyapeeth, Rahuri, XII, 1-4.
Hermans, C. and Verbruggen, N. 2005. Physiological characterization of $\mathrm{Mg}$ deficiency in Arabidopsis thaliana. $J$. Exp. Bot., 418: 2153-2161.

Hermans, C., Bourgis, F., Faucher, M., Strasser, R.J., Delrot, S. and Verbruggen, N. 2005. Magnesium deficiency in sugar beets alters sugar partitioning and phloem loading in young mature leaves. Planta, 220: 541549.

Hermans, C., Jhonson, G.N., Strasser, R.J. and Verbruggen, N. 2004. Physiological characterization of magnesium deficiency in sugar beet: acclimation to low magnesium differentially affects photosystems I and II. Planta, 220: 344-355.

Kossowski, W. and Strojny, Z. 1983.Chemical analysis of substrate and leaves as a method of determining gerbera nitrogen and magnesium nutrition requirements.Prace-Instytutusadownictwa-I-Kwiaciarstwa-W-

Kierniewichach-B-Roliny-Ozdobne. 8: $111-121$.

Kumar, A.M. and Soll, D. 2000. Antisense HEMA1 RNA Expression Inhibits Heme and Chlorophyll Biosynthesis in Arabidopsis. Plant Physiol., 122: 4955.

Sujatha, K., Gowda, J.V. and Khan, M.M. 2002. Effects of different fertigation levels on gerbera under low cost greenhouse. J. Ornamental Horticult., 5(1): 54-59.

\section{How to cite this article:}

Shiva Kumar Udayana, N.B. More and Anandkumar Naorem. 2017. Evaluation of nutrient concentration and uptake in magnesium and iron deficient gerbera. Int.J.Curr.Microbiol.App.Sci. 6(6): 1399-1407. doi: https://doi.org/10.20546/ijcmas.2017.606.164 